\title{
Second Primary Cancers - Causes, Incidence and the Future
}

\author{
Druhé nádory - přičiny, incidence a budoucnost
}

\author{
Koubkova L., Hrstka R., Dobes P., Vojtesek B., Vyzula R. \\ Regional Centre for Applied Molecular Oncology, Masaryk Memorial Cancer Institute, Brno, Czech Republic
}

\begin{abstract}
Summary
Thanks to continually improving screening programs, diagnostic, and treatment methods, the survival rate in newly diagnosed cancer patients is increasing. With this improvement in survival, attention is now being focused on potential long-term complications such as multiple primary tumors, which represent a leading cause of late non-relapse mortality. The number of patients who survive cancer diagnosis is growing by $2 \%$ each year. Multiple primary neoplasms have become the third most common finding in oncology since 1890's, when they were first described. This review aims to summarize recent information regarding the multiple primary neoplasms, elucidate the definition, etiology, association with the primary cancer treatment, genetic and environmental dispositions and finally, it recapitulates new approaches to identification of the risk factors for multiple cancers.
\end{abstract}

\section{Key words}

neoplasms multiple primary - treatment-related cancers - SEER program

\section{Souhrn}

Díky stále se zlepšující diagnostice a pokrokům v léčbě se zvyšují počty přeživších onkologických pacientů. Na druhou stranu je nutné věnovat zvýšenou pozornost prípadným komplikacím léčby primárního nádoru, jako jsou např. druhé nádory, které v konečném důsledku představují hlavní příčinu úmrtí pacienta. Počet pacientů, kteří přežijí prvotní onkologickou diagnózu se každoročně zvyšuje asi o $2 \%$. Od 90 . let 19 . století, kdy byly vícenásobné primární malignity poprvé popsány, se staly třetí nejběžnější nádorovou diagnózou. Tento přehledový článek stručně shrnuje recentní informace o vícenásobných primárních novotvarech, jejich definici, etiologii, souvislosti s léčbou primárního nádoru, genetických dispozicích, vlivu faktorů životního prostředí i nových přístupech vhodných $\mathrm{k}$ jejich identifikaci.

\section{Klíčová slova}

novotvary vícečetné primární - s léčbou spojené nádory - SEER program
This work was supported by the European Regional Development Fund and the State Budget of the Czech Republic RECAMO CZ.1.05 /2.1.00/03.0101, GA ČR P206/12/G151, IGA NT13794-4/2012 and by Institutional Resources for Supporting the Research Organization provided by the Ministry of Health of the Czech Republic to Masaryk Memorial Cancer Institute MH CZ - DRO (MMCl, 00209805).

Tato práce byla podpořena Evropským fondem pro regionální rozvoj a státním rozpočtem České republiky RECAMO CZ.1.05/2.1.00/03.0101, GA ČR P206/12/G151, IGA NT13794-4/2012 a prostředky institucionální podpory výzkumné organizace MOÚ poskytnuté MZ ČR - DRO (MOÚ, 00209805).

The authors declare they have no potential conflicts of interest concerning drugs, products, or services used in the study.

Autoři deklarují, že $v$ souvislosti s predmětem studie nemají žádné komerční zájmy.

The Editorial Board declares that the manuscript met the ICMJE "uniform requirements" for biomedical papers.

Redakční rada potvrzuje, že rukopis práce splnil ICMJE kritéria pro publikace zasílané do biomedicínských časopisů.

prof. MUDr. Rostislav Vyzula, CSc. Regional Centre for Applied Molecular Oncology

Masaryk Memorial Cancer Institute Zluty kopec 7

65653 Brno

Czech Republic

e-mail:vyzula@mou.cz

Submitted/Obdrženo: 2. 7. 2013

Accepted/Přijato: 18. 8. 2013 


\section{Introduction and definitions}

Cancer is a multifactorial disease and the second most common cause of death after cardiovascular diseases. The onset of cancer is a long-term process involving interactions between many genetic and environmental factors. Continuous progress is being made in the fields of early cancer detection, diagnostic sub-classification and targeted treatments, leading to an apparent survival benefit in patients with malignancy. On the other hand, cancer survivors are at higher risk of developing another malignancy compared with the general population. Longer life span, allowing another carcinogenic process to occur, the susceptibility of older tissues to carcinogenic molecular changes together with toxic effects of radiotherapy and chemotherapy in different genetic backgrounds are all risk factors implicated in the etiology of multiple primary neoplasms/cancers (MPNs). In the 1890's, MPNs appeared rarely and they were considered curiosities. However, since that time, MPNs have become the third most common cancer diagnosis and now they constitute $18 \%$ of all cancers diagnosed in the US Surveillance, Epidemiology and End Results cancer registries [1]. Regarding Europe, for instance in Czech Republic the incidence of MPNs is more than 11\% [2]. This tendency is growing rapidly and requires thorough surveillance by means of new screening methods in order to detect second or even third neoplasms at an early stage. When considering second primary cancers, one should be aware of their precise definition to avoid any bias in their study. In 1889 MPNs were defined by Billroth [3] as tumors that have different histological appearance, arise in different locations and produce their own metastatic deposits. Because of these strict criteria and difficulties with recognition they were only poorly studied. The definition was modified by Warren and Gates in 1932 [4]. According to them, each tumor has to present definite attributes of malignancy, the tumors have to be histologically distinctive and the possibility of one being a metastasis of the other must be ruled out [4]. Performing meta-analyses or literature reviews therefore encounters the problem of incoherent terms used to de- fine multiple primary neoplasms. In some papers, MPNs differ just in histology, or have the same histology but arise in different organs [5].

MPNs are generally divided in two major groups - synchronous and metachronous. There are many studies defining synchronous tumors as two or more primary malignancies diagnosed within a six-month period, while metachronous cancers are detected in sequence with a time interval of more than six months [6]. However, this definition is not generally accepted. For instance, cancer registries in United States - Surveillance, Epidemiology and End Results (SEER) Program applies a 2-month rule to distinguish synchronous from metachronous tumors, whereas the definition provided by the World Health Organization's International Agency for Research on Cancer (IARC) does not take time into account and reckons only one tumor per organ per person in a life-time. Another problem lies in the criteria used to define whether the second tumor is indeed a new entity or whether it is a recurrence/metastasis of the primary tumor. In general, the diagnosis of MPN can be established on condition that it has a histological pattern different from the first tumor and it is localized at a different anatomical site [7]. Yet, this definition is not entirely appropriate, since metastases can have unalike histology and multiple primaries with similar histology can arise in one organ. Thus, there is a need of creating a consensus on the definition of multiple primary cancers for the sake of comparing date throughout various cancer registries. The introduction of next-generation sequencing technology or the identification of new specific mutations, translocations or copy-number variations in common oncogenes represent promising tools to resolve the problem, since the clonal tumors have the same origin and share common mutations, in contrast to multiple primaries that present with different mutation spectra.

\section{Etiology of second or later cancers (genetic, environmental and life style factors)}

Carcinogenesis is a multi-step and complex process that requires the accumula- tion of changes in cell signaling, defense mechanisms and the tissue microenvironment. Hanahan and Weinberg [8] originally described six essential cellular functions that might be play a role in tumor manifestation: self-sufficiency in growth signals, insensitivity to growth suppressors, apoptosis evading, unlimited replicative potential, sustained angiogenesis, tissue invasion and metastasis. Together they constitute a rationale for understanding malignant diseases. The ongoing research brought about two new hallmarks to this concept - reprogramming of energy metabolism and immune response evasion [9]. Moreover, normal cells within and in proximity to the tumor help to acquire some of these traits and serve as tumor microenvironment. There are specific genetic factors predisposing to the development of certain types of cancers, but mainly it is the life style and exposure to harmful environmental factors that play a crucial role in carcinogenesis. It has been observed that in the presence of inherited mutations in genes responsible for cell cycle control, DNA repair etc., defense mechanisms are impaired and cancer growth is facilitated. However, cancers caused by inherited genetic disorders represent only $3-10 \%$ of all cancers diagnosed annually [10]. The majority of tumors (90-97\%) is non-hereditary and can be attributed to environment and lifestyle influences. Cancer risk depends also on the dose of carcinogens and the person's individual susceptibility, which is influenced by age, sex, genetics, ethnicity, immune and nutritional status. Moreover, there are many low-penetrance genes being identified which [11], in combination with environment and lifestyle factors, can have higher prevalence than high-penetrance genes like $B R C A 1$ or $B R C A 2$.

Smoking is a risk factor for several cancer types, mainly lung and esophagus, and is regarded as the cause of $25-30 \%$ of all deaths from cancer and $87 \%$ from lung cancer [12]. Tobacco smoke is proved to contain carcinogenic mutagens and alters a number of cell signaling pathways predominantly by activation of nuclear transcription factor (NF-KB) that induces tumorigenesis, via 
inflammatory and other gene products. Approximately $30-35 \%$ of all cancer-related deaths in USA are linked with the diet. Consumption of high-caloric and fatty food was observed to increase the risk of malignancy to some extent varying with type of cancer. For example, diet is associated with development of colorectal cancer, leading to death in approximately $70 \%$ of cases [12]. Infectious agents, such as hepatitis B and $C$ viruses, human papilloma viruses or Helicobacter pylori, are well-known risk factors for specific cancers, and it was estimated that $17.8 \%$ of neoplasms are associated with an infection [12]. An Asian study showed that HBV and HCV carriers have a 20-25-fold increased risk of liver cancer [13]. Environmental pollution has been linked to various types of cancer (chiefly in lung) since the 18th century [13]. These factors, in a close interaction with genetic predispositions, are implicated in the etiology of first primary tumors and might, naturally, contribute to MPNs development, however the extent of genetic contribution in comparison with the environmental risk factors for MPNs onset is so far unknown and remains to be elucidated. Curtis et al [14] conducted a study analyzing each of more than 50 types of adult and 18 types of childhood primary cancer sites in relationship to the development of subsequent cancers with regards to host factors. The relative risk of second cancer differed markedly by age at diagnosis of the first tumor and was found to be 6-fold higher in childhood cancer survivors. Still, they found that the greatest burden of MPNs was diagnosed at ages 30-59 years. Geryk et al [15], who analyzed data from Czech National Cancer Institute, found the highest burden of MPNs among patients in age group 50-69 years. As for racial differences, the black population was found to be at greater risk of developing another cancer [14]. Comparing female and male gender, women are generally at slightly higher risk of MPNs than men. The acquisition of MPNs is also marked by the influence of tobacco smoking and alcohol abuse. The subsequent cancer burden depends on many other influences including host and/or environ- mental factors but also on the follow-up and surveillance period.

Nielsen et al [16] analyzed whether the excess risk of developing MPN is rather associated with concordant secondary malignancies, or the excess risk is higher in different types of metachronous tumors. They found a 2.2 -fold risk of the MPN being of the same type as the first, whereas the risk for discordant tumors was only 1.1-fold. These findings indicate that risk of MPNs is probably specific to cancer type and is most likely driven by the individual's genetic and lifestyle risk factors.

Regarding late effects of treatment, these can be attributed to genetic polymorphisms in genes encoding enzymes that participate in drug metabolism, such as glutathione S-transferase, cytochrome P450 or thiopurine methyltransferases. These enzymes are linked with therapy-related MPNs, but not in the manner of absolute predictors, inasmuch as there are other host factors that influence drug efficacy such as age, race, sex, body size, renal and hepatic functions etc. [17].

The risk of radiotherapy-related cancers is increased especially in retinoblastoma (RB) patients [17-22]; retinoblastoma is characterized by mutation in $R B 1$ gene that plays an important role in the cellular response to DNA damage. $R B 1$ mutation carriers are predisposed to a high-risk of osteosarcomas, soft-tissue sarcomas, melanoma etc.

The next chapters address several cancer diagnoses as first primary cancers and review the literature for recent information on subsequent tumors (MPNs) in relation to tumor therapy, genetics, environmental and life-style factors. Breast and colorectal cancer, as the most common cancer types, Hodgkin's lymphoma as a representative of radiosensitive disease and head and neck squamous cell carcinoma because of its smoking and alcohol-related nature.

\section{Colorectal Cancer}

Colorectal cancer is one of the most common cancers diagnosed worldwide and $3 \%$ of colorectal cancers are associated with positive family history [23]. Hereditary non-polyposis colorectal can- cer (HNPCC) is a syndrome caused by mutations in mismatch repair genes (mostly hMSH2 and hMLH1). Mutation carriers have increased relative risks of developing cancers of the corpus uteri, ovary, stomach, pancreas, small intestine, kidney and nervous system [7,23]. As reported by Evans et al [7], the lifetime risk of MPNs among HNPCC carriers was $78 \%$ for colorectal cancer, $43 \%$ for cancer of the corpus uteri, $19 \%$ for stomach cancer, $18 \%$ for biliary tract cancer, $10 \%$ for urinary tract cancer, and $9 \%$ for ovarian cancer. Among patients with no family history of colorectal carcinoma, the results of some studies investigating the risk of MPN are ambiguous. For example, in studies by Noura et al [24] or Lee et al [25]. The stomach has been recognized as the major site of MPN after curative surgery. On the other hand, results of a study carried out by Curtis et al [14] show that prostate cancer is the most frequent MPN in non-hereditary colorectal cancer syndrome. Median age at diagnosis of most MPNs was between 60 and 70 years and the secondary tumors occured within five-year interval after the resection of primary colorectal cancer [24]. In addition, colorectal cancer has been reported to be the most common type of MPN in patients with gastric carcinoma [25], indicating a possibility of shared predisposing factors and the need of thorough surveillance of these patients.

\section{Breast Cancer}

Breast cancer is the most common cancer in women throughout the world. The risk of developing breast cancer in women is markedly increased by deleterious mutation in BRCA1 and BRCA2 tumor suppressor genes. Approximately 2-5\% of all breast cancers are believed to be familial [14]. Among BRCA1/2 carriers, the chances of developing breast cancer is about five times higher than in the general population. In addition to breast cancer, inheriting a mutation in the $B R C A 1$ gene increases the risk of developing ovarian, cervical, uterine, pancreatic and colon cancer, whereas BRCA2 mutations increase the risk of ovarian, pancreatic, stomach, gallbladder and bile duct cancers and mela- 
noma. Besides the inherited mutations in $B R C A 1$ and $B R C A 2$, also mutations in PTEN or TP53 were proved to increase the risk of subsequent cancers [26]. However, data reflecting the relationship of family history of breast cancer and the risk of MPNs development are not consistent. For instance, in study by Kmet et al [27] a 2-fold increase in the risk of colon cancer among patients with a family history of breast cancer has been reported. In contrast, Curtis et al [14] observed only a small increase of colon cancer development among patients with primary breast cancer. Nevertheless, familial tumors account only for a small proportion of MPNs.

Breast cancer survivors with negative family history are also at increased risk of developing MPNs. The most common MPNs occur predominantly in the opposite breast [14]. Apart from the breast, the majority of MPNs has been observed in the digestive tract (mainly colon and stomach), respiratory system (lung) and female genital system (ovary and corpus uteri) $[14,28-30]$. Susceptibility to MPNs appears to be related to race and the age at initial diagnosis. It has been reported that young age and black race are strong predictors of increased risk of subsequent malignancies in breast cancer patients [14]. Breast cancer is often treated with surgery followed by radiotherapy. There are several studies investigating the effects of radiotherapy for breast cancer on the incidence of MPNs [31-35]. For example, it has been reported that breast cancer patients particularly are at increased risk of sarcoma or lung cancer in a period longer than five years after radiotherapy treatment [33]. Zhang et al [31], who examined the effect of radiotherapy on the onset of MPN following breast cancer, with respect to age and menopausal status, observed an increased risk of MPNs in patients over 50 years of age, which might be related to their menopausal status. It is not only radiotherapy treatment that can have the impact on MPN onset following breast cancer. Adjuvant chemotherapy and hormonal therapy by tamoxifen are another widely used treatment modalities. In particular, tamoxifen has been reported to contribute to development of endometrial cancer. On the other hand, tamoxifen reduces the risk of subsequent breast cancer [14]. In conclusion, the risk of second malignancies following breast cancer depends on each individual's features like age, race, reproductive characteristics (low parity or late age at first birth) as well as the type of treatment used.

\section{Hodgkin's Lymphoma}

Hodgkin's lymphoma is a highly curable disease affecting both children and adults [36]. One of the most serious late side effects of treatment is the emergence of MPN affecting both age groups. Survivors of $\mathrm{HL}$ have more than three times greater risk of solid tumors in comparison with the general population [37]. Among the most common MPNs in childhood HL survivors radiation-related solid tumors dominate, yet, patients are also at greater risk for chemotherapy-associated hematologic tumors [38]. Childhood and adolescent $\mathrm{HL}$ is treated by combination of chemotherapy and radiation therapy with 5-year survival rate of more than $90 \%$ [38]. Breast and thyroid cancers and bone/soft tissue sarcomas belong to the most frequently diagnosed solid MPNs [38]. Survivors of adult-onset HL are also at greater risk of solid MPNs, with the role of gender in second breast cancer onset remaining unclear. The most common MPN following the diagnosis of $\mathrm{HL}$ are cancers of the breast, lung and intestine. Differences in MPN risk rates between childhood and adult-onset $\mathrm{HL}$ survivors have been described in the literature. While the risk of breast cancer is not affected by exposure to alkylating agents in childhood, there was observed a dose-related risk reduction in adults exposed to alkylating agents treatment. MPNs of the lung represent a negligible entity among childhood HL survivors, whereas in adults they are one of the most common MPNs. There are many factors that can influence MPN onset following HL. For instance, tobacco users treated with chemotherapy and radiotherapy ( $\geq 5$ Gy to the area of the lung) have almost 50 -fold higher relative risk of developing lung cancer as a second malignancy [38].

\section{Squamous Cell Carcinoma of Head} and Neck

Squamous cell carcinoma of the head and neck (HNSCC) is the fifth most common cancer worldwide [39]. MPNs represent a major cause of morbidity and mortality among patients successfully treated for early-stage HNSCC [40]. Approximately $15-25 \%$ of HNSCC survivors develop MPN within five years after the initial diagnosis [41]. The lung (29.8\%), head and neck (28.0\%), prostate (14.2\%) and bladder (5.1\%) are the major sites of MPNs [41]. HNSCC are known to harbor many chromosomal abnormalities (within 3p, 9p, 13q, or 17p) and dysregulation of several cellular pathways triggered by e.g. p53, p21, p16, cyclin D1, K-RAS, EGFR, NOTCH1 etc. have been reported to contribute to the onset of HNSCC [41-43]. Wu et al [41] examined the relationship between single nucleotide polymorphisms (SNPs) and risk of MPNs and/or recurrences. They found six chromosomal SNPs and seven mitochondrial SNPs (mtSNPs) significantly associated with higher risk of MPNs and/or recurrence. The most significant SNP identified in relation to MPNs was located in MKI67 gene, encoding an important cell cycle proliferation marker. Another study [44] showed that a common polymorphism in codon 72 of $\mathrm{p} 53$ is correlated with MPN development in HNSCC survivors. Li et al [44] compared the distribution of codon 72 homozygous Arg/Arg and Pro/Pro genotypes and found the p53 Pro alleles are more frequent among patients with MPN, suggesting that the p53 72 Pro might be associated with increased risk of MPN development. Lei et al [39] investigated a role of two polymorphic variants of CDKN1A (coding for $\mathrm{p} 21^{\text {WAF1 }}$ ) in the onset of MPNs among HNSCC patients. The $\mathrm{p} 21^{\text {WAF } 1}$ protein belongs to family of cyclin dependent kinase (CDK) inhibitors and modulates cell cycle control by cell growth inhibitions. Carriers of the CDKN1A 98 CA/AA and 70 CT/TT genotypes were at 1.8-fold risk of MPNs compared with patients with the homozygous wild-type genotype [39]. Moreover, Lei et al [39] found significantly elevated MPNs risk associated with any p21 ${ }^{\text {WAF } 1}$ variant genotypes in non-Hispanic whites, al- 
Tab. 1. Selected primary cancer sites with multiple primary cancers from Surveillance, Epidemiology, and End Results (SEER - 9 areas), 1973-2009.

\begin{tabular}{|c|c|c|c|c|c|}
\hline \multirow[b]{2}{*}{ primary cancer site } & \multicolumn{5}{|c|}{ Multiple primary cancers } \\
\hline & counts & $\begin{array}{l}\text { counts within } \\
0-5 \text { months }\end{array}$ & $\begin{array}{c}\text { counts 6+ } \\
\text { months }\end{array}$ & total & $\begin{array}{c}\% \text { after } \\
6 \text { months }\end{array}$ \\
\hline oral cavity and pharynx & 82,237 & 2,550 & 13,025 & 15,575 & 15.8 \\
\hline digestive system & 623,206 & 19,196 & 47,444 & 66,640 & 7.6 \\
\hline respiratory system & 460,100 & 8,571 & 23,733 & 32,304 & 5.2 \\
\hline bones and joints & 7,031 & 52 & 420 & 472 & 6.0 \\
\hline breast & 475,534 & 11,850 & 65,978 & 77,828 & 13.9 \\
\hline female genital system & 217,286 & 5,021 & 22,806 & 27,827 & 10.5 \\
\hline male genital system & 495,546 & 7,406 & 55,223 & 62,629 & 11.1 \\
\hline urinary system & 213,678 & 8,887 & 32,471 & 41,358 & 15.2 \\
\hline brain and other nervous system & 50,235 & 292 & 1,166 & 1,458 & 2.3 \\
\hline endocrine system & 59,982 & 664 & 5,473 & 6,137 & 9.1 \\
\hline lymphoma & 147,843 & 1,952 & 13,570 & 15,522 & 9.2 \\
\hline myeloma & 38,774 & 545 & 1,943 & 2,488 & 5.0 \\
\hline leukemia & 91,441 & 1,238 & 6,071 & 7,309 & 6.6 \\
\hline
\end{tabular}

cohol drinkers, smokers and for patients who received a DNA-damaging agent in their treatment. Association of SNPs with risk of MPNs in patients with early stage HNSCC were described in terms of miRNA (micro ribonucleic acid) biogenesis pathway and miRNA-targeted genes. These 22 nucleotide long molecules, which posttranscriptionally regulate gene expression, have been considered as master regulators of gene networks and play a role in tumorigenesis as well [45]. Recently, genetic profiles of SPMs in HNSCC patients were analyzed in order to determine genetic alterations that help to distinguish recurrence from distant metastases or MPNs. Several similarities between primary malignancy and MPN (gain of $B C L 2 L 1$, amplifications of CCND1 and EMS1) and differences between primary malignancy and recurrence have been found [42].

Second primary cancer incidence in Surveillance, Epidemiology and End Results (SEER) cancer registries

A longer follow-up period and advances in cancer treatment, together with an early detection and supportive care, has not only prolonged patient survival but has also increased the number of cancer survivors by $2 \%$ each year [46]. To date, about $70 \%$ of all cancer patients survive at least five years after the diagnosis [47]. Due to this growing population of long-term survivors, monitoring the late consequences of cancer therapy becomes essential. In addition to cancer treatment as a predisposing factor, MPNs can also emergeas a result of environmental and lifestyle factors as well as gene-environment and gene-gene interactions [46].

Nowadays, there is a plethora of works addressing MPNs occurrence after various primaries for certain cohorts of patients. These studies usually include estimates on the extent of excess risk of MPN attributable to different treatment modalities (surgery alone, radiotherapy, chemotherapy and combinations), age, sex and race, in a chosen type of cancer. However, the comparison of results is hampered by the different layout of the analyses, as well as the use of different definitions of MPNs or different follow-up periods. Another issue to mention is the large number of combinations of first and second tumor sites. One of the most sophisticated databases monitoring development of MPNs is Surveillance, Epidemiology and End Results (SEER) registry. SEER collects data on malignancies of various locations and origins throughout the United States. The data collection began in 1973 within a limited number of registries and it has continually expand in terms of areas and demographics included. SEER cancer registries currently cover approximately $28 \%$ of the US population. The most common cancer sites of MPNs between 1974 and 2003 based on the SEER cancer registries were the urinary bladder (16\%), oral cavity and pharynx (15\%), uterus (11\%), breast (10\%), colon and rectum $(10 \%)$, skin $(10 \%)$ and kidney and renal pelvis (10\%). The least frequent MPN was liver cancer (1\%) [48]. To obtain more recent data, we performed a brief analysis of MPNs in the period 1973-2009 based on SEER databases. For this purpose, the SEER software package SEERStat 8.01 was used. We included patients from SEER- 9 areas who were diagnosed from 1973 to 2009 with all kinds of MPNs for which there were available data. We excluded cases with the cancer diagnosis estab- 
lished by a death certificate or autopsy. To avoid data duplication in case of simultaneous tumors, we applied a six months rule (only MPNs that appeared at least six months after the initial diagnosis were counted) to distinguish synchronous and metachronous tumors. Tab. 1 shows primary cancer sites and number of patients who developed MPNs within a follow-up period of six months after the initial diagnosis up to December 31, 2009. In contrast to Hayat et al [48], our data (up to 2003) show the oral cavity and pharynx (15.8\%), urinary system $(15.2 \%)$, breast (13.9\%), male genital system (11.1\%) being the most common primary cancer sites. The least frequent MPNs occurrence was found in pancreas $(0.8 \%)$ indicating that the spectrum of primary cancer sites of MPNs might have been slightly changed.

\section{Approaches to identify factors associated with multiple cancers}

Advances in screening, early detection and treatment of many tumors has significantly increased patient survival and quality of life. Progress in human cancer medicine has generally been driven by a combination of cytogenetic technologies, the adoption of gene cloning advances and the use of model organisms to define cancer gene function. Completion of the human genome sequence facilitated the development of progressive technologies, such as DNA microarrays or next generation sequencing, that allow further investigations of common genetic variations associated with risk of primary tumors, tumor phenotype and susceptibility to cancer in general. These novel approaches allow examination of many common genetic variants in different individuals to evaluate their association with a specific trait, hence being often denoted as genome-wide association studies (GWAS) or whole genome association studies (WGAS). The most common method of GWAS is the case-control setup, in which one healthy control group and one case group affected by a certain disease are compared. Thanks to the development of these high-throughput methods, the possibility to determine a variety of predisposing factors linked with multiple tumors, especially inherited mutations, SNPs and epigenetic patterns such as DNA and histone modifications, have become available.

Hierarchical clustering of gene expression patterns, based on large-scale analysis of gene expression using DNA array technology, has been successfully used to identify subtypes of many tumors that exhibit distinct clinical behavior [49-51]. Microarrays are used in cancer biology for several purposes such as the identification of SNPs, mutations, tumor classification, identification of potential biomarkers etc. Supervised analyses are applied to define a set of genes with expression patterns enabling to distinguish tumors on the basis of an external parameter such as survival, recurrence or response to therapy and could be performed to identify poor prognosis gene expression signatures predictive of recurrence of many primary cancers $[41,49,51]$. However, due to the biological complexity of gene expression, it is of critical importance to acknowledge the experimental designs discussed in each article that deals with expression profiling, if there are to be statistically and biologically valid conclusions drawn from the data.

Since the genomes of all cancer cells carry somatic mutations [52], systematic sequencing appears to be a promising tool for the identification of all classes of somatic mutations in individual cancer genomes, yielding complete spectra of somatic mutations [53]. As many cancer genomes have already been sequenced and the genetic fundamentals of cancer at least partially "uncovered", introduction of new approaches for diagnosis, risk stratification and individualized treatment of cancer patients is expected to follow. Gradually, thousands of comprehensive, high-quality spectra of somatic mutations, SNPs and epigenetic modifications providing powerful insights into the processes of DNA damage, mutation, repair and selection will be generated. These data will become the basis for a concise picture reflecting the pathological relevance of individual human genome alterations. Taken together, DNA microarrays as well as next generation sequencing is a powerful re- search tool; however, it remains unclear whether these technologies will ever be fully adopted in clinical practice, mainly due to the complexity of sample preparation, intra-tumor heterogeneity and other technical aspects [54].

The application of the new approaches mentioned above has provided the first hints in efforts to find weak points in the genome that are crucial for understanding the etiology of MPNs. A GWAS conducted on pediatric Hodgkin's disease survivors treated with radiation therapy has identified two genetic variants at chromosome 6q21 strongly associated with risk of MPN development [55]. The PRDM1 gene lies inside the risk locus, encoding a zinc finger transcriptional repressor that is frequently lost in many cancer types [56]. These findings implicate PRDM1 in the etiology of radiation therapy-induced MPNs. Similarly, identifying mutations that occur as a direct result of therapy (such as tAML) provide a useful screening tool for early detection of MPNs.

\section{Conclusions and perspectives for the future}

Most papers addressing the issue of MPNs and published at the beginning of this millennium linked the incidence of particular MPNs predominately to high doses of chemo-/radio-therapy or their combination used to treat primary tumors. The advances in molecular biology and genomics in the past 10 years had significantly raised the chances of increasing the efficiency of cancer diagnostics and treatment. The decryption of the entire human genome sequence and improved technologies for DNA sequencing assessments of genetic variation raises the possibility to analyze each individual's genotype and possibly to predict disease susceptibility. Large genomic data sets are being constantly generated and provided in public databases, pushing biological and biomedical research to a whole new level.

Many studies have reported an increased number of patients who survived their first malignancy. However, this growing group of survivors is directly affected by significantly elevated risk of MPNs development. Ear- 
lier studies have more or less failed to systematically examine gene-therapy interactions, for many reasons such as the absence of detailed therapeutic exposure data, small sample sizes and lack of sufficiently sensitive yet robust methods. A systematic assessment of the role of drug-metabolizing enzymes, DNA repair proteins and drug pharmacokinetics in the development of MPNs is currently a major issue in understanding the reasons why additional cancers occur in certain individuals, and developing intervention strategies to reduce the risk and/or to improve the treatment of these MPN.

\section{References}

1. Berrington de Gonzalez A, Curtis RE, Kry SF et al. Proportion of second cancers attributable to radiotherapy treatment in adults: a cohort study in the US SEER cancer registries. Lancet Oncol 2011; 12(4): 353-360. doi: 10.1016/S14 70-2045(11)70061-4.

2. Dusek L, Muzik J, Gelnarova E et al. Cancer incidence and mortality in the Czech Republic. Klin Onkol 2010; 23(5): 311-324.

3. Billroth T (ed.). Geral surgical pathology and therapeutics in 51 Vorlesungen: a textbook for students and physicians in fifty-one lectures. 14th ed. Berlin: G. Rerimer 1889. 4. Warren S, Gates O. Multiple primary malignant tumors - a survey of the literature and statistical study. Am J Cancer 1932; 16: 1358-1414.

5. Luciani A, Ascione G, Marussi D et al. Clinical analysis of multiple primary malignancies in the elderly. Med Oncol 2009; 26(1): 27-31. doi: 10.1007/s12032-008-9075-x.

6. Demandante CG, Troyer DA, Miles TP. Multiple primary malignant neoplasms: case report and a comprehensive review of the literature. Am J Clin Oncol 2003; 26(1): 79-83.

7. Evans HS, Møller H, Robinson D et al. The risk of subsequent primary cancers after colorectal cancer in southeast England. Gut 2002; 50(5): 647-652.

8. Hanahan D, Weinberg RA. The hallmarks of cancer. Cell 2000; 100(1): 57-70.

9. Hanahan D, Weinberg RA. Hallmarks of cancer: the next generation. Cell 2011; 144(5): 646-674

10. Roukos DH. Genome-wide association studies: how predictable is a person's cancer risk? Expert Rev Anticancer Ther 2009; 9(4): 389-392. doi: 10.1586/era.09.12.

11. Broeks A, Schmidt MK, Sherman ME et al. Low penetrance breast cancer susceptibility loci are associated with specific breast tumor subtypes: findings from the Breast Cancer Association Consortium. Hum Mol Genet 2011; 20(16): 3289-3303. doi: 10.1093/hmg/ddr228.

12. Anand $P$, Kunnumakkara $A B$, Sundaram $C$ et al. Cancer is a preventable disease that requires major lifestyle changes. Pharm Res 2008; 25(9): 2097-2116. doi: 10.1007/s11095-008-9661-9.

13. Park S, Bae J, Nam BH et al. Aetiology of cancer in Asia. Asian Pac J Cancer Prev 2008; 9(3): 371-380.

14. Curtis RE, Freedman DM, Ron E et al. New Malignancies Among Cancer Survivors: SEER Cancer Registries, 1973-2000. National Cancer Institute. In: Bethesda MD. NIH Publ 2006.

15. Geryk E, Dite P, Kozel J et al. Cancer multiplicities in the Czech population. Cas Lek Cesk 2010; 149(4): 178-183.

16. Nielsen SF, Nordestgaard BG, Bojesen SE. Associations between first and second primary cancers: a po- pulation-based study. CMAJ 2012; 184(1): E57-E69. doi: 10.1503/cmaj.110167.

17. Travis LB, Rabkin CS, Brown LM et al. Cancer survivorship-genetic susceptibility and second primary cancers research strategies and recommendations. J Natl Cancer Inst 2006; 98(1): 15-25.

18. Marees T, Moll AC, Imhof SM et al. Risk of second malignancies in survivors of retinoblastoma: more than 40 years of follow-up. J Natl Cancer Inst 2008; 100(24): $1771-1779$

19. Marees T, van Leeuwen FE, de Boer MR et al. Cancer mortality in long-term survivors of retinoblastoma Eur J Cancer 2009; 45(18): 3245-3253. doi: 10.1016/j. ejca.2009.05.011.

20. Kleinerman RA, Tucker MA, Tarone RE et al. Risk of new cancers after radiotherapy in long-term survivors of retinoblastoma: an extended follow-up. J Clin Oncol 2005; 23(10): 2272-2279

21. Kleinerman RA, Yu CL, Little MP et al. Variation of second cancer risk by family history of retinoblastoma among long-term survivors. J Clin Oncol 2012; 30(9): 950-957. doi: 10.1200/JCO.2011.37.0239.

22. Moll AC, Dommering CJ, Bosscha Ml et al. Risk factors for the incidence of second cancers in survivors of retinoblastoma with a family history. J Clin Oncol 2012; 30(24) 3028. doi: 10.1200/JCO.2012.43.7640.

23. Hemminki K, Li X, Dong C. Second primary cancers after sporadic and familial colorectal cancer. Cancer Epidemiol Biomarkers Prev 2001; 10(7): 793-798.

24. Noura S, Ohue M, Seki Y et al. Second primary cancer in patients with colorectal cancer after a curative resection. Dig Surg 2009; 26(5): 400-405. doi: 10.1159/000229991.

25. Lee SH, Ahn BK, Baek SU. Multiple primary cancers in extracolonic sites with colorectal cancer. Int J Colorectal Dis 2009; 24(3): 301-304. doi: 10.1007/s00384-008-0583-0. 26. Evans HS, Lewis CM, Robinson D et al. Incidence of multiple primary cancers in a cohort of women diagnosed with breast cancer in southeast England. Br J Cancer 2001; 84(3): 435-440.

27. Kmet LM, Cook LS, Weiss NS et al. Risk factors for colorectal cancer following breast cancer. Breast Cancer Res Treat 2003; 79(2): 143-147.

28. Khalil S, Ceccarelli F. Colorectal cancer after breast cancer: magnitude of risk in clinical practice and in the literature. Tumori 2009; 95(1): 28-31.

29. Mellemkjaer L, Friis S, Olsen JH et al. Risk of second cancer among women with breast cancer. Int J Cancer 2006; 118(9): 2285-2292.

30. Soerjomataram I, Louwman WJ, de Vries E et al. Primary malignancy after primary female breast cancer in the South of the Netherlands, 1972-2001. Breast Cancer Res Treat 2005; 93(1): 91-95.

31. Zhang W, Becciolini A, Biggeri A et al. Second malignancies in breast cancer patients following radiotherapy: a study in Florence, Italy. Breast Cancer Res 2011; 13(2): R38. doi: 10.1186/bcr2860

32. Brown LM, Chen BE, Pfeiffer RM et al. Risk of second non-hematological malignancies among 376,825 breas cancer survivors. Breast Cancer Res Treat 2007; 106(3): 439-451.

33. Matesich SM, Shapiro CL. Second cancers after breast cancer treatment. Semin Oncol 2003; 30(6): 740-748.

34. Chander R, Kapoor NK, Dhawan BN. Effect of picroliv on glutathione metabolism in liver and brain of Mastomys natalensis infected with Plasmodium berghei. Indian J Exp Biol 1992; 30(8): 711-714

35. Zablotska LB, Neugut Al. Lung carcinoma after radiation therapy in women treated with lumpectomy or mastectomy for primary breast carcinoma. Cancer 2003; 97(6): 1404-1411.

36. Franklin J, Pluetschow A, Paus M et al. Second malignancy risk associated with treatment of Hodgkin's lym phoma: meta-analysis of the randomised trials. Ann Oncol 2006; 17(12): 1749-1760
37. Thomas A, Mailankody S, Korde N et al. Second malignancies after multiple myeloma: from 1960s to 2010s. Blood 2012; 119(12): 2731-2737. doi: 10.1182/blood-20 11-12-381426.

38. Ng AK, Kenney LB, Gilbert ES et al. Secondary malignancies across the age spectrum. Semin Radiat Oncol 2010; 20(1): 67-78. doi: 10.1016/j.semradonc.2009.09.002. 39. Lei D, Sturgis EM, Liu Z et al. Genetic polymorphisms of p21 and risk of second primary malignancy in patients with index squamous cell carcinoma of the head and neck. Carcinogenesis 2010; 31(2): 222-227. doi: 10.1093/carcin/bgp279.

40. Khuri FR, Lee JJ, Lippman SM et al. Randomized phase III trial of low-dose isotretinoin for prevention of second primary tumors in stage I and II head and neck cancer patients. J Natl Cancer Inst 2006; 98(7): 441-450.

41. Wu X, Spitz MR, Lee JJ et al. Novel susceptibility loci for second primary tumors/recurrence in head and neck cancer patients: large-scale evaluation of genetic variants. Cancer Prev Res (Phila) 2009; 2(7): 617-624. doi: 10.1158/1940-6207.CAPR-09-0025.

42. Gutierrez VF, Marcos CA, Llorente JL et al. Genetic profile of second primary tumors and recurrences in head and neck squamous cell carcinomas. Head Neck 2012; 34(6): 830-839. doi: 10.1002/hed.21824.

43. Agrawal N, Frederick MJ, Pickering CR et al. Exome sequencing of head and neck squamous cell carcinoma reveals inactivating mutations in NOTCH1. Science 2011; 333(6046): 1154-1157. doi: 10.1126/science.1206923.

44. Li F, Sturgis EM, Chen X et al. Association of p53 codon 72 polymorphism with risk of second primary malignancy in patients with squamous cell carcinoma of the head and neck. Cancer 2010; 116(10): 2350-2359. doi: 10.1002/cncr.25072.

45. Zhang $X$, Yang $H$, Lee JJ et al. MicroRNA-related genetic variations as predictors for risk of second primary tumor and/or recurrence in patients with early-stage head and neck cancer. Carcinogenesis 2010; 31(12): 2118-2123. doi: 10.1093/carcin/bgq177.

46. Travis LB. The epidemiology of second primary cancers. Cancer Epidemiol Biomarkers Prev 2006; 15(11): 2020-2026.

47. Choi M, Craft B, Geraci SA. Surveillance and monitoring of adult cancer survivors. Am J Med 2011; 124(7): 598-601. doi: 10.1016/j.amjmed.2010.07.031.

48. Hayat MJ, Howlader N, Reichman ME et al. Cancer statistics, trends, and multiple primary cancer analyses from the Surveillance, Epidemiology, and End Results (SEER) Program. Oncologist 2007; 12(1): 20-37.

49. Bertucci F, Finetti P, Cervera $N$ et al. Gene expression profiling and clinical outcome in breast cancer. OMICS 2006; 10(4): 429-443.

50. Perou CM, Sorlie T, Eisen MB et al. Molecular portraits of human breast tumours. Nature 2000; 406(6797): 747-752 51. Pollack JR, Perou CM, Alizadeh AA et al. Genome-wide analysis of DNA copy-number changes using CDNA microarrays. Nat Genet 1999; 23(1): 41-46.

52. Stratton MR, Campbell PJ, Futreal PA. The cancer genome. Nature 2009; 458(7239): 719-724. doi: 10.1038/nature07943.

53. Pleasance ED, Cheetham RK, Stephens PJ et al. A comprehensive catalogue of somatic mutations from a human cancer genome. Nature 2010; 463(7278): 191-196. doi: 10.1038/nature08658.

54. Thomas D. Gene-environment-wide association studies: emerging approaches. Nat Rev Genet 2010; 11(4): 259-272. doi: $10.1038 /$ nrg2764.

55. Best T, Li D, Skol AD et al. Variants at $6 q 21$ implicate PRDM1 in the etiology of therapy-induced second malignancies after Hodgkin's lymphoma. Nat Med 2011; 17(8): 941-943. doi: 10.1038/nm.2407.

56. Beroukhim R, Mermel CH, Porter D et al. The landscape of somatic copy-number alteration across human cancers. Nature 2010; 463(7283): 899-905. 